\title{
Young People, Precarious Employment and Nationalism in Poland: Exploring the (Missing) Links
}

\begin{abstract}
ADAM MROZOWICKI \& JUSTYNA KAJTA
Institute of Sociology, University of Wrocław, ul. Koszarowa 3, 51-149 Wrocław, Poland. Email: adam.mrozowicki@uwr.edu.pl

This article explores the relevance of economic and cultural (identity-based) factors in the emergence of nationalist sentiments among young people in Poland. It discusses the changing labour market situation of young workers, involving their precarisation and critically reviews existing accounts of new nationalism in Poland. In the body of the article, based on the analysis of biographical narrative interviews with young nationalist activists and right-wing supporters, the subjective justifications of their far-right views are analysed. It is concluded that the central motives for supporting the agenda of the nationalist movement by our informants are not directly connected with their economic situation, but related to their search for solid, clear and unambiguous foundations of social order and their biographical identities.
\end{abstract}

\section{Introduction}

Over the last few years, it has been observed that there is a growing presence and increasing activity of nationalist organisations and political parties in Poland. Even though it is hard to estimate the membership of radical nationalist organisations due to the lack of reliable statistics, the rapidly increasing number of participants in the Independence Day Marches - from around 10,000 people in 2010 to 60,000 in 2017 and 250,000 in 2018, when it was supported by the government, clearly indicates their potential for attracting new supporters. In party politics, the victory of the right-wing conservative Law and Justice Party (Prawo i Sprawiedliwość, PiS) in the presidential and parliamentary elections in 2015 showed that there is a general revival of right-wing attitudes within Polish society. Both discursive and political opportunities seem to be now favourable for the nationalists' mobilisation. First, we can observe a more general radicalisation of public discourse, including the wave of hate speech directed against cultural, sexual and ethnic minority groups 
(Winiewski et al. 2017). Second, the Law and Justice government seems to be much less determined than the previous government of Civic Platform and Polish People's Party in persecuting far right supporters for the cases of racist and xenophobic activities. ${ }^{1}$ What is more, the ruling party is well disposed towards the events organised by the radical nationalist milieu, e.g. the Independence Day Marches. In 2015, when they organised it under the slogan 'Poland for Poles. Poles for Poland', the Polish president, Andrzej Duda, sent them an official letter expressing his appreciation for their contribution to the building of Polish identity. In 2017 and 2018, when the world media focused on the racist slogans during the march, the members of the government defended the organisers and stressed the incidental nature of such statements during the event.

The aim of this article is to discuss the basis of nationalist mobilisation in Poland with particular emphasis on the subjective motives of supporting the movement by young people. The basic dilemma addressed in the paper can be summarised in the following questions: are the primary motives of joining and/or supporting nationalist organisations by young people economic and do they reflect their changing position on the labour market, including their precarisation? Or, perhaps, the new nationalist movement is driven predominantly by non-economic factors? The analysis presented in the article points towards the latter explanation. Following the discussion of the theoretical background and the Polish context, based on available literature and secondary data, we present the results of the analysis of 30 biographical narrative interviews with young participants of the Polish nationalist movement. ${ }^{2}$ We also refer to the observations from the PREWORK project based on a sample of 63 biographical narrative interviews with young people, aged 18-35, in temporary, low-paid jobs, and unemployed, collected in 2016-2017. ${ }^{3}$

\section{Precarious Times: The Changing Economic and Political Situation in Poland}

Poland belonged to the frontrunners of neoliberal transformation in 1989, which contributed to subsequent waves of 'crawling crises' (Maciejewska et al. 2016, 229-254). Their result was the expansion of precarious work, which can be understood as 'employment that is uncertain, unpredictable and risky from the point of

1. One of the examples of greater permissiveness could be the liquidation of the Council for the Prevention of Racial Discrimination, Xenophobia and Related Intolerance by the Law and Justice (PiS) government in April 2016.

2. This part of the empirical evidence comes from the $\mathrm{PhD}$ project of Justyna Kajta entitled 'The identity of the participants of the Polish nationalist movement'.

3. The interviews for the PREWORK project were carried out in three large and two mid-sized cities as well as two smaller towns in Poland by the team of researchers including Magdalena Andrejczuk, Jacek Burski, Olga Czeranowska, Aleksandra Drabina-Różewicz, Katarzyna Jarguz, Mateusz Karolak, Agata Krasowska, Adam Mrozowicki, Karolina Szczepaniak. The project PREWORK 'Young precarious workers in Poland and Germany: a comparative sociological study on working and living conditions, social consciousness and civic engagement' is funded by the National Science Centre in Poland and the German Research Foundation (DFG), the NCN project number UMO2014/15/G/HS4/04476, the DFG project number TR1378/1-1. 
view of the worker' (Kalleberg 2009, 2), often identified but not reducible to non-standard contracts and low-paid jobs.

The recent waves of precarisation strongly affected young people. According to the European Labour Force Survey (Eurostat), Poland is the EU country with the second highest share of workers with temporary contracts $(24.3 \%$ in 2018 for aged 15-64 and 62.6\% for the youngest population, 15-24 years old). Young people aged 15-24 are also more often employed with civil-law contracts (i.e. contracts to perform a specified task and contracts of mandate or business-to-business cooperation with self-employed persons) as compared with the entire working population (Report GUS 2016); with civil-law contracts representing a particular kind of work contract to perform short-term services or tasks, and which exclude workers from some Labour Code rights, such as minimum wage or working-time regulations. Young people in Poland are quite well-educated, but a mismatch between the fields of education and jobs performed is common (Szafraniec 2012).

The counter-forces of labour to these negative developments are fragmented. Trade unions have lost the bulk of their members as a result of restructuring and privatisation, but also due to their incapacity to expand to new economic sectors after 1989. Trade union density in Poland is one of the lowest in the EU $(10-12 \%)$, while other factors of union strength, such as collective bargaining coverage (approximately 15\%) are not much better. As documented by one of our earlier studies (Gardawski et al. 2012), non-unionised young workers in Poland tend to see unions either indifferently or in a negative light, as the bureaucratic structures representing traditional segments of workers, such as miners, teachers or nurses.

Thus, the conditions of precarisation create a socio-economic problem to be politically addressed. Yet, the trust in politicians in Poland after 1989 has not been particularly strong; it reached its lowest in the last 10 years, with trust in political parties staying below 20\% and the government at less than 40\% (Omyła-Rudzka 2016). There is a rather negative attitude towards politicians and political parties among young people:

young people believe that politicians are focused just on their own careers $(92 \%)$ and most of them do not think about the general public interest (82\%). The great majority $(84 \%)$ states that political parties are interested just in gaining the votes, not in following the people's needs. (Messyasz 2015, 65)

A similar divide between political elites and the people was also noted in the recent studies on new authoritarianism (Gdula 2017).

In 2015, this popular discontent with the PO-PSL (Civic Platform-Polish People's Party) government (in power from 2007-2015) paved the way for the victory of the right-wing conservative Law and Justice Party in the parliamentary and presidential elections. The party made many people believe that Poland was bedraggled, weak, dependent on foreign capital and governed by a network of liberal elites who despise 'normal people' in favour of their European and transnational interests. In the same parliamentary elections, the (nominally) left-wing, post-communist social-democratic party (the Democratic Left Alliance) did not enter parliament. Instead, for the first 
time, several far-right candidates representing the National Movement made their way to the Sejm as a part of Paweł Kukiz's party.

Even though the winners of the elections often claimed that it was the support of young people that brought them victory, the outcomes of the representative surveys demonstrate a more complex picture and suggest the existence of an ongoing void in the area of political representation. According to tentative results of the quantitative module in the PREWORK project, in December 2016 only 26.4\% interviewees stated that they were rather satisfied or extremely satisfied with the state of the economy in Poland and only $17.4 \%$ said that they were satisfied or very satisfied with the government. ${ }^{4}$ Despite criticism of the economic and political situation in Poland, no labour-related movement comparable to Spanish indignados has emerged in Poland in recent years. In the next section, we refer to several explanations for this situation.

\section{Explanations for Growing Support of Nationalist Movements}

David Ost and Don Kalb are among the authors who discuss the interconnections between the rise of far-right populism and class-based discontent following neoliberal transformation. According to Ost $(2007,9)$, economic inequalities typical of capitalism, generate emotions that 'need to be organised along some lines or cleavages' and 'for liberal democratic outcomes, economic anger is best organised along class lines, meaning that economic conflicts get expressed as economic conflicts, rather than as ethnic, racial, national or religious ones'. However, in a post-socialist context, class identities tend to be weak and class discourses indeterminate. East European parties tend to avoid the discourse of class which they see as linked to the authoritarian past when every deficiency in the system was explained via the covert workings of the people's enemy. As a result, the mobilisation of the economically disadvantaged is taken over by illiberal parties that make use of cultural frames of reference, including those related to national identity, to oppose the liberal elites.

A similar point is made by Don Kalb $(2011,1)$. He suggests that 'working-class neonationalism is the somewhat traumatic expression of material and cultural disenfranchisement in the neoliberal epoch'. The 'imagined nation' is said to be 'crafted by new political entrepreneurs generating protest votes against neoliberal rule' (Kalb 2011, 13) identified with the bureaucratic and essentially non-democratic European Union and financial global capitalism. Neonationalism can be seen as the 'return of the repressed' (Žižek 2008), in the context in which the language of social class is weak (or delegitimised, as in the case of post-communist Eastern Europe) and the disadvantaged search for other ways of expressing their discontent.

4. Research on the representative sample of the Polish youth aged 18-30, November-December 2016, CATI, $N=1000$, carried out by IQS. The questionnaire was designed by Professor Juliusz Gardawski in collaboration with the German team of the project led by Professor Vera Trappmann. 
The arguments by Ost and Kalb are just two examples of economy-centred explanations. Convincing as they are, they face some problems with respect to the results of empirical research on the Polish far-right movements. First, the basis of such movements is socially heterogeneous. As demonstrated by one of the surveys by the Public Opinion Research Centre (CBOS), 38\% of people aged 18-24 (as compared with 17\% of the general population) generally supported the activities of far-right organisations, such as the All-Polish Youth (Młodzież Wszechpolska) and the National Radical Camp (Obóz Narodowo-Radykalny), with most of the support granted by service workers, skilled workers, farmers and students (Boguszewski and Głowacki 2016). However, another CBOS survey shows that the narrow group of 'engaged right-wing supporters', estimated at $11 \%$ of the $18+$ population in Poland, are usually young men, living in large cities, welleducated and well-off (Roguska 2016). Second, the most frequent participants in various social protests in Poland in the last 15 years were not workers, but the representatives of intelligentsia and professionals (Domański 2015), which shows that, generally, protests in Poland are dominated by slogans other than economic ones. Marches organised by the nationalist milieu as well as their discourse also attract people from different social classes, contrary to popular belief linking radical nationalism with the representatives of popular classes. Third, 'the support for the programs of strengthening the Polish traditional national identity' cannot be seen, as argued by Tomasz Zarycki $(2009,114)$, as mere smokescreens for primary economic problems, but are 'to large extent connected with the need for recognition, enhancing the symbolic capital of large segments of the society stigmatised by the feeling of cultural marginalization'.

The problems of economic explanations of new nationalism call for a closer look at its cultural and identity-centred explanations. Some of the authors refer to general social changes concerning globalisation processes while they explain the rise of new nationalism. Anthony Giddens $(1991,196)$ sees the predilection for dogmatic authoritarianism as a psychological phenomenon which occurs when the feeling of ontological certainty is at risk because of the disruption of the existing order and multiplication of conflicting authorities. Zygmunt Bauman (1991) suggests that people tend to confirm their identity by referring to other people and to affiliate with community in order to avoid loneliness and powerlessness. Looking for stable points of reference and for belonging can lead them to nationalist references, including nationalist milieus. However, it can also be suggested that the differences between economic explanations and identity-centred explanations are relative, as in both cases collective mobilisation is understood as the result of negative effects reflecting, respectively, a disadvantaged material situation or cultural disorientation, conflicting values and the lack of recognition.

Daniel Płatek and Piotr Płucienniczak point at the opportunity structure theory as a distinct group of explanations of the mobilisation of the far right. We include it in more general culture-based explanations, even though they also recognise the role of economic factors. According to the theory, 'the extreme right is not only a byproduct of an anomic situation, but rather an agent seeking favourable opportunities 
and actively adjusting to its social environment' (Płatek and Płucienniczak 2017, 292). Discussing this approach, the authors refer to Rafał Pankowski (2010), who sees the revival of the national democracy tradition, antisemitism and fundamentalist Catholicism as means for representatives of the right-wing to enter mainstream political discourse.

According to the CBOS (the Public Opinion Research Centre) surveys, the differences between those declaring left-wing and right-wing political views in Poland are rather minimal as regards the economic sphere: both categories support progressive taxes and generous state social support while opposing far-reaching privatisation. The differences are mostly visible in the sphere of cultural identities and values. The right-wing supporters are euro-sceptical, convinced of the need for a closer relationship between the State and the Catholic Church, opposed to legalising homosexual relationships, and support a total ban on abortion (Feliksiak 2015).

The most important nationalist organisations, such as the All-Polish Youth (Młodzież Wszechpolska, MW), the National Radical Camp (Obóz NarodowoRadykalny, ONR) and the National Rebirth of Poland (Narodowe Odrodzenie Polski, NOP) rarely refer to economic exclusion in their discourse and activity (Kajta 2018). Even though the movement seems to capitalise on the economically-driven discontent, it lacks a coherent economic programme. The primacy of cultural and identity agenda and the silencing of labour market experiences are also evident in the interviews with members of the nationalist organisations to which we will refer to next.

\section{Between Culture and Economy: The Motives for Young People Supporting the Right}

The remaining part of the article is based on two lots of data. First, these are 30 biographical-narrative interviews with young participants of the Polish nationalist movement derived from the project: 'The identity of the participants of the Polish nationalist movement' carried out by Justyna Kajta. Informants included regional leaders and members of the All-Polish Youth (Młodzież Wszechpolska, MW), the National Radical Camp (Obóz Narodowo-Radykalny, ONR) and the National Rebirth of Poland (Narodowe Odrodzenie Polski, NOP), most of whom (28) were students or university graduates. Second, we draw from the analysis of biographical narrative interviews with young precarious workers collected in the PREWORK project. In the latter case, informants included both university graduates ( 24 cases) and those without tertiary education degrees (39 cases), working with temporary and civil law contracts, trainees or unemployed. The analysis only covers right-wing supporters, which included three core cases and 13 context cases. ${ }^{5}$ The data were

5. We coded as 'core', cases expressing right-wing views those in the narratives of those who joined demonstrations or events organised or co-organised by the far right (MW, NOP, ONR, Ruch Narodowy). Context cases included those who met at least one of following conditions: (1) voting for right-wing parties (Liberty/Wolność, Kukiz '15, PiS); (2) expressing racists, homophobic or antirefugee views. 
analysed using coding techniques typical of grounded theory methodology (Glaser 1978).

The analysis of the interviews with the activists and members of the nationalist organisations demonstrates the heterogeneity of their social background, which has earlier been observed in quantitative research on right-wing supporters (Boguszewski and Głowacki 2016). People we spoke with came from different social classes, have parents with various education degrees and have different economic situations. It does not seem that engagement in the nationalist organisation is the simple result of family socialisation or the answer to economic deprivation. Parents' or grandparents' political beliefs differ. While some of the narrators were brought up in conservative or right-wing families, others' parents support the main oppositional party towards the Law and Justice (PiS) government, Civic Platform (Platforma Obywatelska, PO) or are not interested in politics at all.

Analysis of the interviews shows that the contemporary nationalist movement has diverse ideological frames of reference, which enhances its chances to attract new supporters. Criticising the social and political reality in Poland, narrators refer to the dominance of liberal discourse which is connected by them with the threat to tradition and important values (i.e. religion, nation, family), a passive and manipulated (by the media and liberal politicians) society, and hypocritical media and political milieus. In this context, they define themselves using four main types of identity framing (1) educators of a new patriotic ('awakened') generation; (2) defenders and creators of the Polish identity and history against liberalism, postmodernism and European 'leftism'; (3) anti-systemic activists resisting the 'system' identified with the social, political and economic setting established after 1989, including corrupted ('post-communist') elites, the mass media and an economy subordinated to foreign capital, and politics ignoring the needs of ordinary people; (4) socially and politically engaged citizens involved in 'work at the grassroots' for the nation, its collective memory and forgotten heroes (e.g. the veterans of anti-communist guerrillas) and assisting the disadvantaged and poor, for instance offering gifts to children in children's homes or organising material support for the residents of pre-Second World War Polish territories in the east (Kresowiacy).

The weakness of left-wing organisations in contemporary Poland causes people from different social environments who seek anti-establishment activism, to find themselves in the nationalist milieu. It gives them the opportunity to feel a part of the anti-governmental, anti-systemic movement, to express their dissatisfaction as well as to be socially/politically involved. An example is the narrative of the activist of the All-Poland Youth, Tadeusz:

Tadeusz (MW): The All-Polish Youth or the National Radical Camp have constant and increasing inflow of people or support because they are out of the [political] connections... these organisations are established by young, idealistic people. I think... and there is a very transparent message... a very clear message ... it is uncompromising... 
It seems that the narrators build their identity mainly on that of resistance. It is constructed by social actors who feel (culturally and politically) marginalised and define their situation as devalued by the existing conditions (Castells 1997, 8). The references to the economic situation in Poland are much less common than to political and cultural issues. Even though some narrators critically assess their chances on the labour market and share the experiences of economic emigration and precarious jobs, such themes are usually of secondary importance in their life stories. While the nationalists share similar cultural worldviews and values, they do not have a coherent economic programme. In the interviews collected, heterogeneous economic views were typical: some informants supported radical variants of economic liberalism (e.g. the liquidation of obligatory contributions to the State Insurance Company), while others expressed the need for retaining some elements of the welfare state. Many talked about their lack of interest in the economy:

Marian (ONR): Economy? Honestly I did not think about it, because socialism is my enemy, but I also don't think that liberalism is a way out, free market. Frankly speaking... a mixed system, but it is hard to call it...

Dariusz (NOP): We criticise capitalism and it is like ... litmus paper [... ] concerning the differences... in the All-Polish Youth or National Radical Camp... there are plenty of free-market supporters, the supporters of free-market and capitalism and it has nothing in common with the tradition of Polish nationalism, absolutely nothing in common.

Andrzej (ONR): I often vote for UPR [Real Politics Union], so I have rather extremely liberal views on economics, but I claim that society should be taking up such solidarity, not the state. People... if someone has more [she/he] should share it with those poorer not because someone [the state $-\mathrm{JK}$ ] makes him do it, but because we are people and we should help each other, right.

The lack of coherent economic views seems to be a general aspect of the political and economic consciousness of young people. Other studies on the youth in Poland documented the growing relevance of hybrid models and indecisiveness regarding economic preferences (Gardawski 2017, 116).

Similar observations follow from the analysis of narrative interviews with rightwing supporters among the young precarious workers interviewed within the PREWORK project. On the one hand, there is almost univocal criticism of the high-level politics both on the side of the governing party (Law and Justice) and key parliamentary parties in opposition (such as Civic Platform or.Modern/.Nowoczesna). On the other hand, as compared with left-wing supporters, who often explain their political choices by their criticism of working conditions, right-wing voters and activists refer mostly to cultural factors in justifying their preference for traditional values and social order. An example is Alina, a doctoral student in the field of Polish philology, who supports the Liberty/Wolność party led by the Euro-sceptical Janusz Korwin-Mikke, known also for his public praising of traditional gender roles: 


\begin{abstract}
Alina: It is difficult for me to talk about economic issues [...] The only thing which I can look at are social and cultural issues [...] For instance, I wouldn't like to have immigrants in Poland, right? I really wouldn't like them here. I wouldn't like some relationships, perhaps I'd accept partnership relationships, but the issues of raising children by homosexual couples, it is at least doubtful. Or some quarrels about hanging the cross in a classroom. Poland is a Catholic country, it [the cross - AM] has always been there.
\end{abstract}

In order to support herself during her PhD studies, Alina works on short-term contracts as a copywriter and an academic teacher. Yet, as she explains in other parts of the interview, she is satisfied with her job ('I'm able to support myself doing it and I find pleasure in it') and does not criticise her economic situation. She justifies her political views by non-economic issues related to the influence of her husband ('interested in politics' and supporting the Liberty/Wolność party as well) and, more fundamentally, the need to retain 'conservative' values which she acquired during her upbringing in a rather religious environment in an old mining region in Poland. Such a choice might be seen in terms of defending stable and predictable foundations for individual life strategies in the context of fears of disruption of social order by the expansion of cultural liberalism which is promoted by the liberal media and left-wing circles ('my views are anti-leftist'). Similar to Alina, other right-wing supporters rarely explain their economic attitudes by work or labour market conditions and more often explain their choices by their opposition to liberal elites, the mass-media and 'leftist' milieus, which are seen as threats to the nationhood, tradition and 'normalcy.'

However, there are rare, but interesting, cases in which some general statements about economic situation are included. The first type of such situation is the narratives of aspiring and real 'self-made men' who tend to criticise the undeserved (and often only imagined) 'privileges' of some categories of people, including refugees and those living on welfare. An example is Marian, an IT specialist, who says:

Marian: As far as the refugee issue is concerned, I think it's really like a pumped balloon [...] They were supposed to work in such conditions that my mum who is the citizen of this country would have four times worse conditions. Because such a person would be accepted on welfare, 3-4 thousand PLN per month, they'd receive a flat, they wouldn't need to work or speak Polish [...] I don't respect Poles either who live on welfare [...] I hate parasites [...] I didn't get anything for free.

In the case of Marian, who, following emigration, short-term jobs in construction and production plants, took a loan and invested $€ 2500$ in IT training to get a job in an IT company. Here, anti-establishment political views are combined with radical liberalism and criticism of the welfare system, grounded in a belief in the individual achievements of hardworking people juxtaposed with those 'unwilling to work'. Thus, cultural motives follow economic ones and result in an anti-solidarity vision of a fragmented society of competing individuals which can be occasionally integrated within spectacular manifestations of nationhood, in opposition to generalised cultural Others (i.e. leftists, Muslims, homosexual couples, to mention a few issues tackled in the interview). Unsurprisingly, Marian is fascinated by the 
Independence Marches in Warsaw, which gave him (similar to the other narrators who participated in it in both PREWORK and far-right activist samples) a chance to participate in a festive, albeit ephemeral collectivity united by national symbols ('when you walk in a crowd of tens of thousands with Polish flags, singing the anthem together, this is an incredible experience').

Another type of justification, usually limited to the anti-immigrant component of right-wing views, was more often encountered in the narratives of those economically disadvantaged, in low-skilled and low-paid jobs or unemployed. The need to protect culturally defined community as the source of social embeddedness can be interpreted as a response to the feeling of economic uncertainty and symbolic exclusion, additionally intensified by the fear of becoming dominated by cultural others. An example is Marianna who currently attends job activisation training organised by the Voluntary Labour Corps and links her criticism of refugees with her experiences during migration to the UK:

\begin{abstract}
Marianna: I am not interested in politics. I mean, maybe I am interested a bit, more in the topic of refugees [...] When we were for half a year in Great Britain. I got to hate Islam. Terribly. We lived for three months in C. where there were 30 mosques and no white person in the street, and I had too much of them, they were rude, unpleasant, almost run over us on the pavement. They almost killed our daughter in the pram because they run the car right into the pram, and they wanted to fight us afterwards.
\end{abstract}

Despite the presence of right-wing attitudes among some of the informants in the PREWORK project who were not active members of nationalist organisations, it has to be stressed that in most cases they did not translate into the participation in the nationalist events and mobilisation. What is more important, however, is that in none of these cases was a direct link between precarious work and right-wing social criticism explicitly made. In the case of right-wing activists, nationalist and rightwing views represent a particular kind of 'anti-systemic' (meaning anti-establishment and anti-liberal) counterculture against liberal elites held responsible for the course of system change after 1989. In the broader category of young workers, they seem to reflect the need to retain the traditional principles of social order which can provide some basic security and orientation points in the context of uncertainty and risks only indirectly related to their work situation.

\title{
Conclusion
}

This article sought to answer the question of the social sources for the support of nationalist organisations by a portion of young people in Poland. Even though young workers in Poland have been strongly affected by the expansion of low-paid and temporary employment, no mass left-wing counter-movement emerged in response to such a situation. While the nationalist movements might be fuelled by young people's discontent with the state of the economy and politics in Poland, the distrust of existing political actors and the weakness of left-wing alternatives, 
the analysis of interviews with young right-wing activists and supporters suggests that the direct motives of supporting the agenda of the movement are not directly related to their labour market experiences as precarious workers. Instead, they appear to be connected with their search for what they see as more solid, clear and unambiguous foundations of social order. In opposition to late modern ambivalence, sometimes identified with the views and political agenda of liberal elites, right-wing informants opt for traditional values and clearly bounded, religious or national communities, which provide them with some degree of certainty, a firm axiological orientation and guidelines for life strategies.

Taking into account our preliminary analysis, two hypotheses on the sources of right-wing support can be formulated to guide further research. On the one hand, the right-wing turn among those economically disadvantaged seems to be closely related to their fear of loss of anchoring in reliable communities, which can be seen as a side-effect of their objective precarisation, involving increased mobility (including, among others, emigration and frequent job changes) and economic uncertainty. The inflow of cultural Others, competing with locals (or 'intra-European' migrants) for rare resources, is perceived as additionally disrupting what is socially constructed as a stable and 'safe' lifeworld of the past. On the other hand, and perhaps more surprising, (far) right-wing attitudes also emerge among those better educated and economically better off. Experiencing upwards social mobility, they tend to minimise the biographical relevance of objective precarity and instead focus on the threats to the foundations of Polish nationhood, traditions and values. Yet, at least in some cases, their right-wing views also reflect their occupational careers. The biographical experiences of social rise by the means of individual resourcefulness call into question the legitimacy of social support for Others, who are seen as potential welfare claimants obtaining 'undeserved' privileges and support from the state at the cost of the 'majority' of hard-working people. Undoubtedly, neither of the scenarios allows us to determine a direct relationship between precarity and right-wing turn. However, it can be argued that objective precarisation, involving the fragmentation of collective experiences of workers, creates a favourable ground for the spread and social acceptance of political discourses that promise to re-establish the value and legitimacy of collective reference points known from the past, such as the nation, religion or traditional family.

Further analysis of the relationship between nationalist views and the socioeconomic position of young people requires additional research based on representative samples. Due to the nature of our methodology, the research presented in this article could only suggest the existence of certain mechanisms and patterns and not their statistical distribution in the population of young people in Poland. The curious heterogeneity of young people's economic consciousness and its rather weak relationship with the actual labour market situation calls for further explanation. The ongoing quantitative research within the PREWORK project suggests that 'a part of young people, including those with precarious status, reject not only the intervention of state in economy, but also welfare institutions. They do it in spite 
of being employed in unstable, low-paid contracts, which do not offer them an opportunity of using paid health care services or saving for retirement' (Gardawski 2017, 116). Further in-depth analysis is needed to explore the particular configuration of biographical factors leading to the emergence of such paradoxical views combined with a tendency to reduce uncertainty in relation to other, cultural, dimensions of their social identities.

\section{Acknowledgements}

This article was prepared within the project PREWORK ('Young precarious workers in Poland and Germany: a comparative sociological study on working and living conditions, social consciousness and civic engagement') funded by the National Science Centre in Poland and the German Research Foundation (DFG), the NCN project number UMO-2014/15/G/HS4/04476, the DFG project number TR1378/1-1.

\section{References}

Bauman Z (1991) Modernity and Ambivalence. Cambridge: Cambridge Polity Press. Boguszewski R and Głowacki A (2016) Między patriotyzmem a nacjonalizmem, Report CBOS 151/2016. Warszawa: CBOS. Available at http://www.cbos.pl/ SPISKOM.POL/2016/K_151_16.PDF (accessed 18 September 2019).

Castells M (1997) The Power of Identity. Oxford: Blackwell Publishers.

Domański H (2015) Czy sa w Polsce klasy spoleczne? Warszawa: Wydawnictwo Krytyki Politycznej.

European Labour Force Survey. Eurostat. Available at http://appsso.eurostat.ec.europa. eu/nui/show.do?dataset=lfsa_etpgan\&lang=en (accessed 18 September 2019).

Feliksiak M (2015) Co różni od siebie zwolenników lewicy, centrum i prawicy. Report CBOS 139/2015. Warszawa: CBOS. Available at http://cbos.p1/SPISKOM.POL/ 2015/K_139_15.PDF (accessed 18 September 2019).

Gardawski J (2017) Klasy społeczno-ekonomiczne a normatywne wizje gospodarki. Kultura i Rozwój 1(2), pp. 73-119.

Gardawski J, Mrozowicki A and Czarzasty J (2012) Trade Unions in Poland. Brussels: ETUI.

Gdula M (2017) Nowy autorytaryzm. Warszawa: Wydawnictwo Krytyki Politycznej.

Giddens A (1991) Modernity and Self-Identity. Self and Society in the Late Modern Age. Stanford: Stanford University Press.

Glaser B (1978) Theoretical Sensitivity. Advances in the Methodology of Grounded Theory. Mill Valley: Sociology Press.

Kajta J (2018) Współczesny ruch nacjonalistyczny w Polsce: ramy protestu i tożsamość. In Kowalewski M, Rakusa-Suszczewski M, Rozalska A (eds), $W$ świecie protestu. Idee i narzędzia wspótczesnych ruchów spolecznych. Warszawa: Warszawskie Wydawnictwo Socjologiczne, pp. 61-82.

Kalb D (2011) Introduction. Headlines of nation, subtexts of class: working-class populism and the return of the repressed in neoliberal Europe. In Kalb D and Halmai G (eds), Headlines of Nation, Subtexts of Class. Working-Class 
Populism and the Return of the Repressed in Neoliberal Europe. New York; Oxford: Berghahn Books.

Kalleberg A (2009) Precarious work, insecure workers: employment relations in transition. American Sociological Review 74(1), pp. 1-22. https://doi.org/10.1177/ 000312240907400101

Maciejewska M, Mrozowicki A and Piasna A (2016) The silent and crawling crisis: international competition, labour market reforms and precarious jobs in Poland. In Myant M, Theodoropoulou S and Piasna A (eds), Unemployment and Labour Market Deregulation in Europe. Brussels: ETUI, pp. 229-254.

Messyasz K (2015) Postawy polityczne młodzieży polskiej w świetle badań empirycznych. Wladza Sadzenia 7, 57-79.

Omyła-Rudzka M (2016) Zaufanie spoleczne, Report CBOS 18/2016 (Warszawa: CBOS) Available at http://www.cbos.pl/SPISKOM.POL/2016/K_018_16.PDF (accessed 18 September 2019).

Ost D (2007) The Defeat of Solidarity. Anger and Politics in Postcommunist Europe. Ithaca and London: Cornell University Press.

Pankowski R (2010) The Populist Radical Right in Poland: The Patriots. Routledge: London.

Platek D and Plucienniczak P (2017) Mobilizing on the extreme right in Poland: Marginalization, institutionalization and radicalization. In Jacobsson $\mathrm{K}$ and Korolczuk E (eds), Civil Society Revisited. Lessons from Poland. Oxford; New York: Berghahn Books, pp. 287-313.

Report GUS (2016) Pracujacy w nietypowych formach zatrudnienia, Note 27 January 2016 (Warszawa), Available at https://stat.gov.pl/download/gfx/portalinformacyjny/ pl/defaultaktualnosci/5475/21/1/1/notatka_nietypowe_formy_zatrudnienia_2016_ 01_27.pdf (accessed 19 September 2017).

Roguska B (2016) Aktywność społeczno-polityczna Polaków. Report CBOS 16/2016. Warszawa: CBOS. Available at http://www.cbos.pl/SPISKOM.POL/2016/K_016_ 16.PDF (accessed 6 September 2017).

Szafraniec K (2012) Dojrzewajacy obywatele dojrzewajacej demokracji. O stylu politycznej obecności młodych. Warszawa: Instytut Obywatelski.

Winiewski M, Hansen K, Bilewicz M, Soral W, Świderska A and Bulska D (2017) Contempt Speech, Hate Speech. Report from Research on verbal violence against minority groups. Warsaw: Centre for Research on Prejudices. Available at http:// www.ngofund.org.pl/wp-content/uploads/2017/02/Contempt_Speech_Hate_Speech_ Full_Report.pdf (accessed 19 September 2017).

Zarycki T (2009) Socjologia krytyczna na peryferiach. Kapitał kulturowy jako kluczowy wymiar nierówności. Kultura i Społeczeństwo LII(1), pp. 105-121.

Žižek S (2008) In Defense of Lost Causes. London: Verso.

\section{About the Authors}

Justyna Kajta is a sociologist, post-doc at the Institute of Sociology, University of Wrocław, $\mathrm{PhD}$ in Social Sciences, specialty social movements (University of Wrocław, 2017). Her research interests include nationalism, social movements, identity, borderlands, biographical research and discourse analysis. She is research assistant at the Centre for Regional and Borderlands Studies (University of Wrocław). 
Adam Mrozowicki is a sociologist, associate professor at the Institute of Sociology, University of Wrocław, $\mathrm{PhD}$ in Social Sciences (Catholic University of Leuven, 2009), habilitation degree in social sciences, specialty economic sociology (University of Wrocław, 2016). He specializes in economic sociology and sociology of work and currently co-leads the qualitative module of the NCN-DFG funded PREWORK project. 